PHOTOGRAMMETRY-DERIVED DIGITAL SURFACE MODEL AND ORTHOIMAGERY OF LAND AREAS NEAR RESURRECTION BAY, ALASKA

Matthew S. Balazs, Gabriel J. Wolken, and Katreen Wikstrom Jones

Raw Data File 2018-2

$\$ 1.00$

This report has not been reviewed for technical content or for conformity to the editorial standards of DGGS.

July 2018

State of Alaska

Department of Natural Resources

Division of Geological \& Geophysical Surveys 


\section{STATE OF ALASKA}

Bill Walker, Governor

DEPARTMENT OF NATURAL RESOURCES

Andrew T. Mack, Commissioner

\section{DIVISION OF GEOLOGICAL \& GEOPHYSICAL SURVEYS}

Steve Masterman, State Geologist \& Director

Publications produced by the Division of Geological \& Geophysical Surveys are available to download from the DGGS website (dggs.alaska.gov). Publications on hardcopy or digital media can be examined or purchased in the Fairbanks office:

Alaska Division of Geological \& Geophysical Surveys (DGGS)

3354 College Road | Fairbanks, Alaska 99709-3707

Phone: 907.451 .5010 | Fax 907.451.5050

dggspubs@alaska.gov | dggs.alaska.gov

\section{DGGS publications are also available at:}

Alaska State Library, Historical

Collections \& Talking Book Center

395 Whittier Street

Juneau, Alaska 99801

Alaska Resource Library and

Information Services (ARLIS)

3150 C Street, Suite 100

Anchorage, Alaska 99503

\section{Suggested citation:}

Balazs, M.S., Wolken, G.J., and Wikstrom Jones, Katreen, 2018, Photogrammetry-derived digital surface model and orthoimagery of land areas near Resurrection Bay, Alaska: Alaska Division of Geological \& Geophysical Surveys Raw Data File 2018-2, 6 p. http://doi.org/10.14509/29824
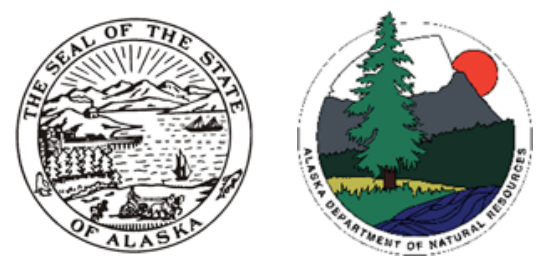


\title{
PHOTOGRAMMETRY-DERIVED DIGITAL SURFACE MODEL AND ORTHOIMAGERY OF LAND AREAS NEAR RESURRECTION BAY, ALASKA
}

\author{
Matthew Balazs², Gabriel J. Wolken ${ }^{1}$, and Katreen Wikstrom Jones ${ }^{1}$
}

\section{ABSTRACT}

The State of Alaska Division of Geological \& Geophysical Surveys (DGGS) produced a digital surface model (DSM) and an orthorectified aerial optical image mosaic (orthoimagery) of the Resurrection Bay watershed, surrounding the city of Seward in south-central Alaska (fig. 1). Aerial photographs and Global Navigation Satellite System (GNSS) data were collected on August 13, 2015, and were processed using Structure-from-Motion (SfM) photogrammetric techniques to create the DSM and orthoimagery. The project was part of an ongoing investigation of the impact of flooding, slope instability, and cryosphere hazards on infrastructure and public safety. For the purpose of enabling open access to geospatial datasets in Alaska, this collection is being released as a Raw Data File with an open end-user license. All files can be downloaded free of charge from the DGGS website (http://doi.org/10.14509/29824).

\section{DATA ACQUISITION}

The State of Alaska Division of Geological \& Geophysical Surveys contracted the collection of digital aerial photographic data on August 13,2015. The aerial photography survey used a fixed-wing airborne platform and was planned so flight lines and photograph frequency provided 60 percent side lap and 80 percent end lap coverage, with an average above-sea-level flying height of $1260 \mathrm{~m}$. The aerial photography survey covered $383 \mathrm{~km}^{2}$, resulting in 4021 photos with $0.2 \mathrm{~m}$ ground sample distance (GSD).

A Nikon D800 camera with AF-Nikkor 28mm f/2.8D lens was used to collect 36.2-megapixel JPEG photographs (7360 x 4912 pixels per image) which were compressed for optimal quality. During the aerial survey, the photograph coordinates were determined using an OxTS GPS-IMU system and a Cirrus Digital Systems intervalometer that linked the camera shutter release to the GPS-IMU. The camera was mounted inside the aircraft with the GPS antenna positioned over the camera. The GPS antenna offset $(X=0.3, Y=0.0, Z=0.94$ ) was corrected during GPS post-processing to solve for the camera coordinates. A Trimble 5700 GPS receiver with a Trimble Zephyr 4-point feed antenna was deployed approximately 160 meters north of the northeast corner of the Seward Airport and was used as the GPS base station for horizontal and vertical control during the aerial survey.

Nineteen photo-identifiable checkpoints were collected by University of Alaska Fairbanks, Geophysical Institute personnel in September 2015 using two Trimble R8s GPS receivers (fig. 2). The base station was located on National Geodetic Survey benchmark X-74 (PID: TT0396), located west of the Seward Airport.

\footnotetext{
${ }^{1}$ Alaska Division of Geological \& Geophysical Surveys, 3354 College Road, Fairbanks, Alaska 99709-3707; gabriel.wolken@alaska.gov ${ }^{2}$ Alaska Division of Geological \& Geophysical Surveys, 3354 College Road, Fairbanks, Alaska 99709-3707; now at University of Alaska Fairbanks, Geophysical Institute, 903 Koyukuk Dr. Fairbanks, Alaska 99775
} 


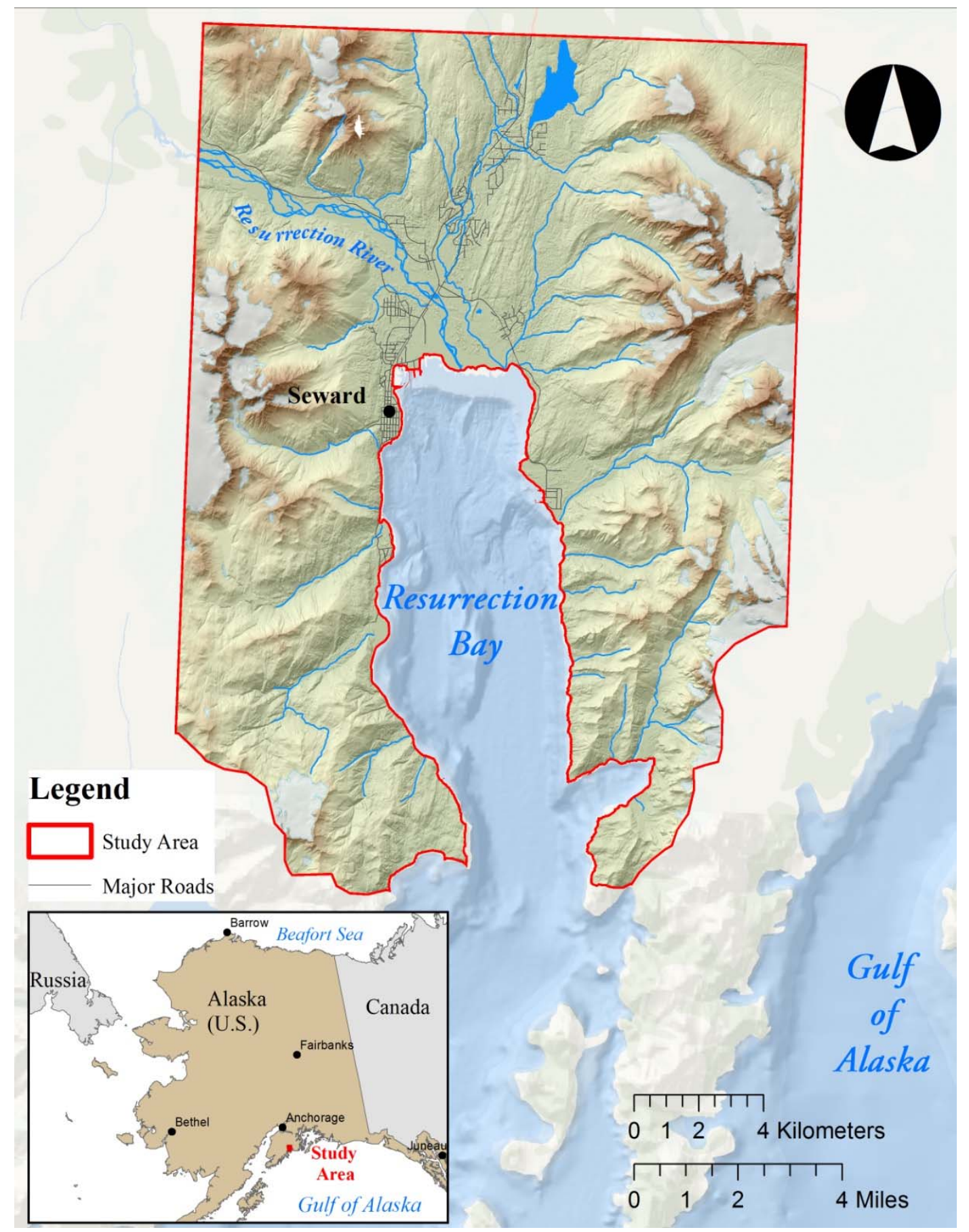

Figure 1. Location and extent of photogrammetry-derived products resulting from the aerial survey conducted on August 13, 2015. 


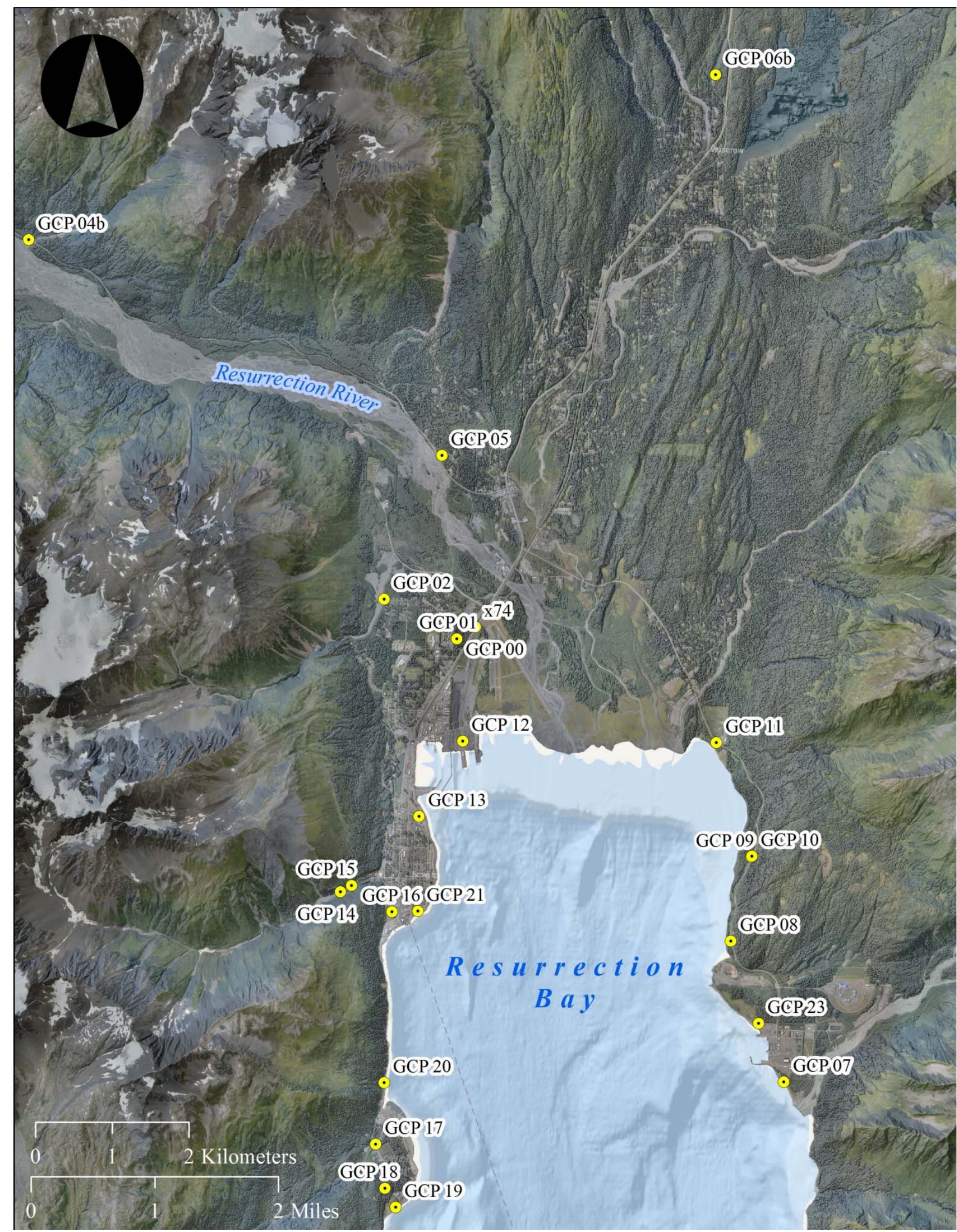

Figure 2. Location of checkpoints used to assess data quality September 2015. 


\section{DATA PROCESSING GNSS}

Aerial survey GPS data were processed using GrafNav GNSS Post-Processing Software, Version 8.40.5121 using post-processing kinematic (PPK) methods. The Trimble Zephyr base station position was corrected using the National Geodetic Survey OPUS with the IGS08 (EPOCH:2015.6162) solution. Both aerial and base GPS data were collected and processed in WGS84 (G1674) using the WGS84 ellipsoid. Standard deviations for the GPS event marker horizontal and vertical positions were less than $0.06 \mathrm{~m}$.

After post-processing, GPS event marker coordinates needed to be converted to the datum most frequently used by DGGS stakeholders. We used the National Oceanic and Atmospheric Administration's VDatum tool to transform the GPS event marker coordinates to the North American Datum 1983 (NAD83; 2011) European Petroleum Survey Group Well Known Identification Number (EPSG) 6337 and the North American Vertical Datum of 1988 (NAVD88; Geoid12A; EPOCH 2010.00). The coordinates are projected in UTM Zone 6 North and are in meters.

GPS event marker coordinates were manually correlated to image filenames to create a camera exterior orientation file for import into the SfM software, Agisoft Photoscan Professional. The exterior

orientation file provides the $\mathrm{X}, \mathrm{Y}, \mathrm{Z}$ positions and Yaw, pitch, and roll for each photograph taken during the survey.

\section{Photogrammetry}

Aerial stereo-photographs were imported into the commercially available Agisoft Photoscan Professional software (Version 1.2.3 build 2331). Photos were processed in Photoscan on a Windows PC to align aerial photos, edit the sparse point cloud, optimize the bundle block adjustment, construct the dense point cloud and triangulated irregular network geometry, and export the natural color (RGB) orthoimagery GeoTIFF.

\section{DATA PRODUCTS}

The data files available for download are tiled DSM and RGB orthoimage GeoTIFFs. All data are projected in UTM Zone 6 North (meters) using the NAD83 (2011; EPSG 26906) horizontal datum and NAVD88 (Geoid12A; EPOCH 2010.00) vertical datum.

\section{Orthoimagery}

The orthoimage is a three-band, 8-bit unsigned GeoTIFF file using LZW compression. The orthoimage has a GSD of $0.2 \mathrm{~m}$ per pixel, and the No Data value is set to 0 . Variable lighting in the orthoimages may result from variable sky conditions during the time of data acquisition.

\section{Digital surface model (DSM)}

DSMs represent surface elevations of all surfaces, including vegetation, vegetation-free land, bridges, buildings, etc. The DSM is a single-band, 32-bit float GeoTIFF files using Lempel-Ziv-Welch (LZW) compression, with a ground sample distance (GSD) of $0.41 \mathrm{~m}$. The No Data value is set to 32767. 


\section{DATA QUALITY}

Horizontal accuracies of the orthoimagery and DSM were assessed using 19 photo-identifiable checkpoints along the road systems in and near Seward, Alaska. Lower horizontal accuracy is possible in areas of extreme terrain, dense vegetation, and heavy shadow. The X-coordinates have a root-meansquare error (RMSE) of $0.32 \mathrm{~m}$ and a mean absolute error (MAE) of $0.28 \mathrm{~m}$. The Y Coordinates have an RMSE of $0.47 \mathrm{~m}$ and a MAE of $0.42 \mathrm{~m}$. The horizontal linear RMSE in the radial direction (RMSE $\mathrm{r}_{\mathrm{r}}$ is $0.57 \mathrm{~m}$.

\begin{tabular}{|c|c|c|c|c|c|c|}
\hline Check Point & Easting $(\mathrm{X})$ & Northing $(Y)$ & Elevation (m) & $\begin{array}{l}\text { Horizontal } \\
\text { offset X (m) }\end{array}$ & $\begin{array}{l}\text { Horizontal offset } \\
\mathrm{Y}(\mathrm{m})\end{array}$ & $\begin{array}{l}\text { Vertical } \\
\text { offset Z (m) }\end{array}$ \\
\hline GCP 00 & 364990.189026 & 6668706.403270 & 12.08 & -0.48 & 0.37 & -0.06 \\
\hline GCP 01 & 364990.2042 & 6668706.363 & 12.06 & N/A & N/A & -0.04 \\
\hline GCP 02 & 364044.063791 & 6669225.506310 & 47.89 & -0.20 & 0.35 & 0.15 \\
\hline GCP 04b & 359417.514721 & 6673903.826340 & 67.89 & -0.34 & 0.61 & 0.75 \\
\hline GCP 05 & 364798.154784 & 6671096.922540 & 20.87 & -0.30 & 0.52 & -0.15 \\
\hline GCP 06b & 368360.057464 & 6676052.310180 & 67.79 & -0.08 & 0.32 & 0.07 \\
\hline GCP 08 & 368559.680233 & 6664762.714420 & 38.01 & -0.38 & 0.73 & 0.06 \\
\hline GCP 09 & 368824.310825 & 6665860.809820 & 60.86 & -0.04 & 0.10 & 0.50 \\
\hline GCP 10 & 368832.126827 & 6665866.313190 & 61.74 & -0.09 & 0.23 & 0.43 \\
\hline GCP 11 & 368371.586338 & 6667355.498050 & 6.08 & -0.48 & 0.49 & -0.08 \\
\hline GCP 12 & 365066.135759 & 6667375.300940 & 7.31 & -0.24 & 0.85 & -0.07 \\
\hline GCP 13 & 364500.346763 & 6666392.240130 & 4.75 & -0.14 & 0.46 & 0.13 \\
\hline GCP 14 & 363473.6677 & 6665404.855 & 68.83 & N/A & N/A & 0.38 \\
\hline GCP 15 & 363620.723744 & 6665488.895810 & 60.57 & -0.17 & 0.21 & 0.69 \\
\hline GCP 16 & 364146.575202 & 6665143.182910 & 11.26 & -0.22 & 0.28 & -0.21 \\
\hline GCP 17 & 363935.320662 & 6662118.063280 & 12.40 & -0.30 & 0.21 & 0.02 \\
\hline GCP 18 & 364056.686632 & 6661541.327030 & 21.78 & -0.66 & 0.43 & -0.16 \\
\hline GCP 19 & 364193.739304 & 6661294.687430 & 3.99 & -0.41 & 0.20 & 0.23 \\
\hline GCP 20 & 364044.143028 & 6662918.463820 & 5.98 & -0.47 & 0.77 & -0.15 \\
\hline GCP 21 & 364484.205699 & 6665155.154920 & 6.08 & -0.17 & 0.39 & -0.04 \\
\hline GCP 23 & 368918.366054 & 6663692.554110 & 5.92 & -0.17 & 0.50 & 0.75 \\
\hline \multirow[t]{7}{*}{ GCP x74 } & 365230.0257 & 6668862.468 & 9.95 & $\mathrm{~N} / \mathrm{A}$ & N/A & 0.27 \\
\hline & & & Mean & -0.29 & 0.42 & 0.12 \\
\hline & & & Std. Dev. & 0.17 & 0.21 & 0.31 \\
\hline & & & Range & 0.62 & 0.75 & 0.96 \\
\hline & & & MAE & 0.28 & 0.42 & 0.28 \\
\hline & & & RMSE & 0.32 & 0.47 & 0.38 \\
\hline & & & RMSE $_{\mathrm{r}}$ & 0.57 & & \\
\hline
\end{tabular}


Total Check Points $=22$

DSM cell size $=0.41 \mathrm{~m}$

Ortho cell size $=.20 \mathrm{~m}$

\begin{tabular}{|l|l|l|l|}
\hline & & & \\
\hline & & Difference: SfM - Survey & \\
& & &
\end{tabular}

Table 1. Accuracy assessment of orthoimage (horizontal) DSM (vertical). All data are projected in UTM Zone 6 North (meters) using the NAD83 (2011; EPSG 26906) horizontal datum and NAVD88 (Geoid12A; EPOCH 2010.00) vertical datum.

Vertical accuracy of the DSM was assessed by comparing the elevation values of 22 checkpoints (described above; fig 2) to the elevation values at the same location in the DSM. The mean vertical offset is $0.12 \mathrm{~m}$, with a RMSE of $0.38 \mathrm{~m}$ and a MAE of $0.28 \mathrm{~m}$. An additional evaluation of the vertical accuracy of the DSM was performed by comparing randomly sampled elevation values of points $(\mathrm{n}=$ 2876) on the road network from a LiDAR-derived digital elevation model (2009) to the elevation values at the same location in the DSM. The mean vertical offset is $0.24 \mathrm{~m}$, with a RMSE of $0.42 \mathrm{~m}$ and a MAE of $0.28 \mathrm{~m}$.

The DSM and orthoimagery have been visually inspected for data errors such as pits, border artifacts, and shifting. Pits and peaks are present over water bodies such as lakes. The end-user should be aware that DSM data were not hydro-flattened. Some small areas along the boundary and northern region of the survey area have NO DATA values, which is due to insufficient overlap (gaps) in the aerial photographic survey in areas of extreme topographic relief. The end user is advised that such areas may have a less accurate geographic position than reported for the rest of the scene.

\section{ACKNOWLEDGMENTS}

This project is funded by Seward Bear Creek Flood Service Area, Kenai Peninsula Borough, DGGS through a State of Alaska Capital Improvement Project, and the University of Alaska Fairbanks, Geophysical Institute. 